\title{
CARRAGEENAN INDUCES CELL DEATH IN RATS BLOOD
}

\author{
O. M. Kopanytsia, M. I. Marushchak, I. Ya. Krynytska \\ I. HORBACHEVSKY TERNOPIL STATE MEDICAL UNIVERSITY, TERNOPIL, UKRAINE
}

Background. Because of its physical and chemical properties, carrageenan is fairly widely used. About $70 \%$ of the carrageenan produced in the world is used in the food industry. Previous studies point to the development of oxidative stress in rats, by means of which carrageenan chronic enterocolitis was modeled.

Objective. The aim of our study was to investigate the level of apoptosis and necrosis in the suspension of leukocytes in rats using $0.5 \%$ and $1.0 \%$ solutions of carrageenan.

Methods. Annexin V (V) binding assays were performed using Annexin V Apoptosis Kit (Sigma Aldrich, USA), caspase rate in leukocyte-lymphocyte blood fractions was determined by spectrofotometry.

Results. It was established that in the experimental application of carrageenan, the percentage of leukocytes with signs of apoptosis in both experimental groups statistically significantly increased. It was detected by the increased activity of effector caspase-3 in 1 month after the experiment in 1.5 times in the $2^{\text {nd }}$ group and in 2.8 times in the $3^{\text {rd }}$ group vs control data that point to caspase-dependent apoptotic pathway in case of carrageenan usage in rats.

Conclusions. Oral use of carrageenan in rats was accompanied by the increase in the number of leukocytes with signs of apoptosis. The animals that consumed $1.0 \%$ solution of carrageenan had more obvious increase in the activity of caspase- 3 in serum relative to a group of rats consuming $0.5 \%$ of carrageenan, proving the increase in the severity of apoptotic processes in intestine with the increase of the dose of carrageenan.

KEY WORDS: carrageenan, apoptosis, caspase-3, rat.

\section{Introduction}

In world practice it is allowed to use about 500 different substances as nutritional supplements, not taking into account a huge number of different types of flavors and some varieties of combined supplements [1].

In the USA, the amount of nutritional supplements (NS) exceeds 1500, in the EU it reaches 1200, in Russia it is 415 , in the Federal Republic of Germany - 350 [2]. By the beginning of $90 \mathrm{~s}$ of the $20^{\text {th }}$ century the use of nutritional supplements in Ukraine was limited in comparison with other countries of Europe and the USA [3], only 194 NS were permitted until 1994 , and according to the Cabinet of Ministers Resolution in 2000, 221 NS were permitted. In addition, in the EU countries it is allowed to use more than 400 flavors in food production.

For food and in medical practice, there is a nutritional supplement called carrageen that is emitted by water extraction from marine algae [4]. This NS (E407) constitutes a family of polysaccharides (also known as Irish moss)

Corresponding author: Mariya Marushchak, Professor, Department of Functional and Laboratory Diagnostics, I. Horbachevsky Ternopil State Medical University, 1 Maydan Voli, Ternopil, 46000, Ukraine

E-mail: marushchak@tdmu.edu.ua

Phone number: +380979981202 contained in the red seaweed Chondrus Crispus, Eucheuma species, Gigartina species, and others. By chemical nature carrageenan is close to agarose and represents unbranched sulfated heteroglycans which molecules are made of residues of derivatives of $D$-galactopyranose with a strict alternation of $\alpha-(1,3)$ and $\beta$ - $(1,4)$ bonds between them, i.e. of repetitive disaccharide units including residues of $\beta-D$ galactopyranose and 3,6-anhydro-a-Dgalactopyranose. Depending on the peculiarities of the structure of disaccharide repeating units, there are three main types of carrageenans, for which the letters of the Greek alphabet are used to define $[1,5,6]$.

Because of its physical and chemical properties, carrageenan is a fairly widely used. About $70 \%$ of the carrageenan produced in the world is used in the food industry: in the production of dairy products (chocolate milk, sherbets, farmer cheese, cheese paste, baby food), meat and fish products (canned food, sausage casings, jelly coatings), seasonings, nonalcoholic beverages, bakery (bread dough, fruit muffins, sugar icing) and confectionery [7].

Previous studies point to the development of oxidative stress in rats, by which carrageenan chronic enterocolitis was modeled [8]. The 
activation of lipid peroxidation is caused by direct stimulation of generation of active forms of oxygen by carrageenan, or indirectly, via the tumor-alpha necrosis factor [9].

The fundamental of carrageenan influence on the body is the development of oxidative stress as one of the mechanisms of damage of intestine as well as the major multiple organ lesions in heart, lungs and liver. Therefore, the aim of our study was to investigate the level of apoptosis and necrosis in the suspension of leukocytes in rats using $0.5 \%$ and $1.0 \%$ solutions of carrageenan.

\section{Methods}

The study was conducted on 36 mature white nonlinear male rats, which were kept on a standard diet at the vivarium of I. Horbachevsky Ternopil State Medical University. During the study we followed the principles of the European Convention for the Protection of Vertebrate Animals Used for Experimental and Other Scientific Purposes (Strasbourg, 1986). The rats were divided into 1 control and 2 experimental groups: the $1^{\text {st }}$ group - control (intact animals); the $2^{\text {nd }}$ group comprised the animals that consumed $0.5 \%$ solution of carrageenan, the $3^{\text {rd }}$ group consisted of the animals that consumed $1.0 \%$ solution of carrageenan. The $2^{\text {nd }}$ and the $3^{\text {rd }}$ groups of animals were provided with free access to $0.5 \%$ solution of carrageenan and $1.0 \%$ solution of carrageenan in drinking water for 1 month $[10,11]$.

Annexin $V(V)$ binding assays were performed using Annexin $V$ Apoptosis Kit (Sigma Aldrich, USA). Apoptotic cells of blood leukocyte suspension were identified by flow cytometry using flow cytometer Epics XL (Beckman Coulter, USA). To distinguish cells that had lost membrane integrity, propidium iodide (PI) was added to a final concentration of $10 \mathrm{mg} / \mathrm{mL}$ before the analysis. The results were presented as a percentage of the total number of cells as follows: live cells - not stained $\left(\mathrm{V}^{-} / \mathrm{PI}\right)$, cells with early signs of apoptosis - stained with annexin $\left(\mathrm{V}^{+} / \mathrm{PI}\right)^{-}$, cells with late signs of apoptosis - positive double fluorescence staining, cells with signs of necrosis - stained with propidium iodide (V-) $\left.\mathrm{PI}^{+}\right)$.

To determine caspase rate in leukocytelymphocyte blood fractions, $0.25 \mathrm{ml}$ of buffer and $50 \mathrm{mcl}$ of $2 \mathrm{mM}$ DEVD-p-NA was added to $0.7 \mathrm{ml}$ of the test liquid. It was incubated for 2 hours at $37^{\circ} \mathrm{C}$; the intensity of light absorbance was measured at $405 \mathrm{Nm}$, which was directly proportional to the product of hydrolysis of Acetyl-Asp-Glu-Val-Asp n-nitroanilide caspase 3-n-nitroanilide [12].

Statistical analysis

The results were analyzed using Statistica 7.0 software and presented as mean with standard error of mean. The differences between all groups were determined using one-way ANOVA, followed by post hoc the Least Significant Difference test. A p-value $<0.05$ was considered statistically significant.

\section{Results}

It was established that with the experimental application of carrageenan, the percentage of leukocytes with signs of apoptosis in both experimental groups increased significantly (Table 1). Thus, the percentage of $\mathrm{V}^{+} / \mathrm{PI}$-cells in the $2^{\text {nd }}$ group increased in 1.9 times, and in group 3 - in 2.2 times vs the control indexes $(p<0.001)$. The percentage of leukocytes with later signs of apoptosis increased significantly, with respect to control: in group 2 - in 8.9 times, in group 3 - in 22.3 times $(p<0.001)$. It should be noted that the level of necrotic cells when introducing $0.5 \%$ carrageenan did not significantly differ from the normal indices, while the use of $1.0 \%$ solution of carrageenan in drinking water caused the increase of $\mathrm{V}^{-} / \mathrm{PI}^{+}$ -cell in 1.7 times $(p<0.001)$.

Caspases in general are important mediators in apoptosis, especially caspase-3, which is the main caspase effector that cleaves cell substrates. It was established that the activity of caspase- 3 effector in 1 month of the experiment increased in 1.5 times in the $2^{\text {nd }}$ group and in 2.8 times in the $3^{\text {rd }}$ group vs control data that proved the caspase-dependent apoptotic pathway in case of carrageenan use for rats (Fig. 1).

\section{Discussion}

Caspase- 3 is probably the best understood of the mammalian caspases in terms of its specificity and roles in apoptosis. Overall, recent progress has generally confirmed the notion of multiple, complex death pathways (some of which require caspase- 3 in specific cell types) that converge on common events including cell shrinkage, blebbing, chromatin condensation and DNA. Two established ways of apoptosis include internal or mitochondrial, involving protein family $\mathrm{Bcl}-2$, cytochrome $\mathrm{C}$ and caspase - 9 and external with the activation of caspase-8 linking a specific cell receptor Fas- and soluble tumor necrosis factor receptors on the cell 
Table 1. Indicators of cell death in serum of the rats in experimental use of carrageenan Me (Q25-Q75)

\begin{tabular}{|l|c|c|c|}
\hline \multicolumn{1}{|c|}{ Index } & Control & $2^{\text {nd }}$ group & $3^{\text {rd }}$ група \\
\hline Alive leukocytes, \% & $\begin{array}{c}95.76 \\
(95.28 ; 96.77)\end{array}$ & $\begin{array}{c}90.05^{*} \\
(89.26 ; 90.43)\end{array}$ & $\begin{array}{c}83.87 * \# \\
(82.62 ; 86.11)\end{array}$ \\
\hline Leukocytes with early signs of apoptosis, \% & $\begin{array}{c}3.05 \\
(2.20 ; 3.68)\end{array}$ & $\begin{array}{c}5.89 * \\
(5.55 ; 6.20)\end{array}$ & $\begin{array}{c}6.73^{*} \# \\
(5.83 ; 7.55)\end{array}$ \\
\hline Leukocytes with late signs of apoptosis, \% & $\begin{array}{c}0.36 \\
(0.10 ; 0.60)\end{array}$ & $\begin{array}{c}3.19 * \\
(2.78 ; 3.65)\end{array}$ & $\begin{array}{c}8.02 * \# \\
(6.75 ; 8.73)\end{array}$ \\
\hline Leukocytes with signs of necrosis, \% & 0.83 & 0.86 & $1.39 * \#$ \\
& $(0.65 ; 0.98)$ & $(0.73 ; 0.98)$ & $(1.20 ; 1.61)$ \\
\hline
\end{tabular}

Notes: * - the difference between the control and the experimental group is statistically significant $(p<0.05-0.001)$ \# - the difference between the $2^{\text {nd }}$ and the $3^{\text {rd }}$ study groups is statistically significant $(p<0.05)$

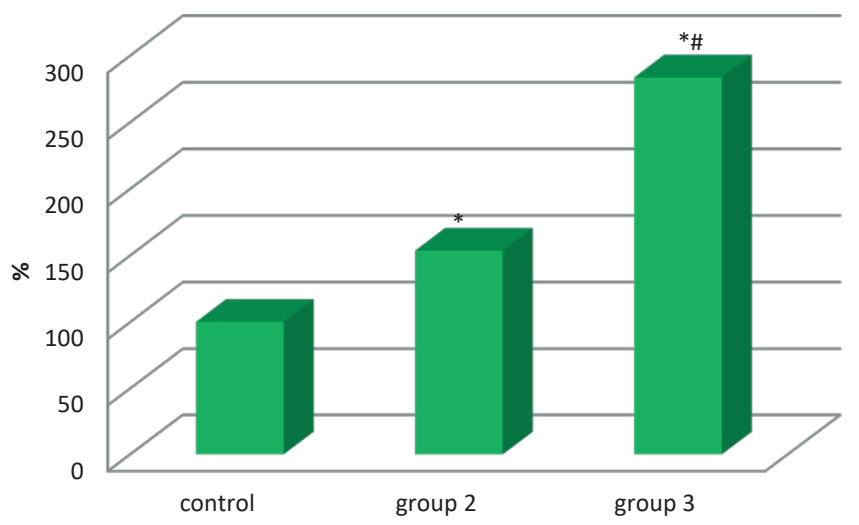

Fig. 1. Caspase-3 level in case of carrageenan intoxication (* - significant difference compared with the control group, \#- significant difference compared with the experimental groups).

surface [13]. Caspase-3 is the most involved pathway which should be generated from its inactive protein (procaspase-3), caspase 3 is required for some apoptosis features (chromatin condensation, DNA damage and apoptotic body formation) and its part may take place before cell viability suppression starts [14]. Hridneva SV notes that in chronic enterocolitis endothelial functions are impaired, which manifests itself in the activation of free radical oxidation processes with underlying decrease in the activity of the antioxidant system that explains the excessive production of ROS [15] and cell death. The activity of caspase-3 increases with increased carrageenan concentration, that proves a more obvious enterocyte apoptosis with the increase in daily intake of carrageenan. At the same time, animals of the $3^{\text {rd }}$ group have a more obvious increase in the activity of caspase- 3 in serum, indicating the increase in the severity of apoptotic processes in intestine. The obtained data contradicts the results of some studies that prove that exposure of human intestinal epithelial cells to carrageenan in vitro does not lead to the activation of caspase-3, caspase-7 or increased percentage of fragmented DNA, suggesting no apoptotic alterations following carrageenan exposure [16]. Otherwise, the results of other studies evidence that carrageenan induced chronic gastroenterocolitis is accompanied by the decrease in the activity of PARP and elevation of MMP-2, MMP-9 and caspase-3 in blood serum of animals [17]. The results are controversial and require detailed consideration. Therefore, further research is warranted to elucidate the role of carrageenan in intestinal caspase-depending cell death that may help define novel nutritional strategies for hindering the development of gut diseases.

\section{Conclusions}

Oral use of carrageenan in rats was accompanied by the increase of the number of leukocytes with signs of apoptosis: $\mathrm{V}+/ \mathrm{PI}-$ - cells in the $2^{\text {nd }}$ group increased in 1.9 times, and in the $3^{\text {rd }}$ group - in 2.2 times, $\mathrm{V}+/ \mathrm{PI}^{+}$-cells increased in 8.9 and 22.3 times, compared with the control $(p<0.001)$; the percentage of leukocytes with later signs of apoptosis was significantly increased too $(p<0.001)$. Animals that consumed $1.0 \%$ solution of carrageenan had more obvious increase in the activity of caspase- 3 in serum relative to the group of rats consuming $0.5 \%$ carrageenan, proving the increase in the severity of apoptotic processes in intestine with the increase in the dose of carrageenan. 


\title{
КАРАГІНАН СПРИЧИНЯЄ ЗАГИБЕЛЬ КЛІТИН КРОВІ ЩУРІВ
}

\author{
О. М. Копаниця, М. І. Марущак, І. Я. Криницька \\ ТЕРНОПІЛЬСЬКИЙ ДЕРЖАВНИЙ МЕДИЧНИЙ УНІВЕРСИТЕТ IMЕНI І. Я. ГОРБАЧЕВСЬКОГО, ТЕРНОПІЛЬ, УКРАЇНА
}

\begin{abstract}
Вступ. Завдяки своїм фізико-хімічним властивостям карагінан досить широко застосовується, а близько 70\% усього виробленого в світі продукту використовується в харчовій промисловості. Попередні дослідження вказують на те, що введення карагінану при моделюванні хронічного ентероколіту викликає розвиток оксидативного стресу.

Метою дослідження стало вивчення рівня апоптозу та некрозу в суспензії лейкоцитів у щурів при застосуванні 0,5\% і 1,0\% розчинів карагенану.

Методи. Аналіз зв'язування анексину V(V) проводили з використанням набору Sigma Aldrich, CША; рівень каспази у суспензії лейкоцитів та лімфоцитів крові шурів визначали спектрофотометрично.

Результати. Встановлено, що при застосуванні карагінану відсоток лейкоцитів з ознаками апоптозу в обох експериментальних групах статистично достовірно збільшувався. Активність каспази-3 зростала в 1,5 рази у 2-й групі і в 2,8 рази в 3-й групі у порівнянні з контрольними даними, які вказують на каспазо-залежний шлях апоптозу клітин при введенні карагінану.

Висновки. Пероральне застосування карагінану в щурів супроводжувалося збільшенням кількості лейкоцитів з ознаками апоптозу. Тварини, які споживали 1,0\% розчину карагінану, мали більш значуще збільшення активності каспази-3 в сироватці відповідно до групи шурів, які споживали 0,5\% каррагінану, що доводить дозо-залежний ефект апоптотичних процесів у кишечнику.

КЛЮЧОВІ СЛОВА: карагінан; апоптоз; каспаза-з; щури.
\end{abstract}

\section{References}

1. Nechaev AP, Kochetkova AA, Zaytsev AN. Nutritional supplements. M.: Kolosm; 2001. [In Russian].

2. Flavoring substances and natural sources of flavourings. Strasbourg; 1992.

3. Smoliar VI. Problems of using nutritional supplements in Ukraine. Abstracts of the International Scientific and Technical Conference / NUKHT. K.: Nauka; 1998. [In Ukrainian].

4. Correc G, Barabanova A, Tuvikene R, Truus K, Yermak I, Helbert W. Comparison of the structures of hybrid $\mathrm{k}-/ \beta$-carrageenans extracted from Furcellaria lumbricalis and Tichocarpus crinitus. Carbohydrate Polym. 2012;88:31-6. doi:10.1016/j. carbpol.2011.11.052

5. Buldakov AS. Nutritional supplements. M.: DeLiPrint, 2001. [In Russian].

6. Nechaev AP, Traubenberg SE, Kochetkova AA. Food Chemistry. Spb.: GIORD, 2003. [In Russian].

7. Osmanyan RG. Prospects of using carrageenans in confectionery production (for the production of jelly sweets with functional properties. Food and processing industry. Abstract Journal. 2008;2:432.

8. Lisnianska NV, Marushchak MI, Antonyshyn IV, Mialiuk OP. Chronic enterocolitis combined with streptozotocin-induced diabetes in rats: mechanism of oxidative stress development. International Journal of Medicine and Medical Research. 2017; 3(2):59-63. https://doi.org/10.11603/ ijmmr.2413-6077.2017.2.8035. [In Ukrainian].

9. Tkachenko AS, Gopkalov VG, Martyinova SN. The method of correction of chronic carrageenaninduced gastroenterocolitis with antioxidant vitamins. Bulletin of Biology and Medicine. 2015; 3(1):315-7. [In Ukrainian].
10. Gubina-Vakulyk GI, Kolousova NG, Ivanenko TO, Gorbach TV, Korobchanskyy VO. Method of modeling chronic gastroenterocolitis. Patent of Ukraine. № a201014510, 2012. [In Ukrainian].

11. Moyana TN, Lalonde JM. Carrageenaninduced intestinal injury in the rat - a model for inflammatory bowel disease. Ann Clin Lab Sci. 1990; 20(6):420-6.

12. Hug H, Los M, Hirt W, Debatin K-M. Rhodamine 110-linked amino acids and peptides as substrates to measure caspase activity upon apoptosis induction in intact cells. Biochemistry. 1999; 38:13906-11.

13. Illinska IF. Apoptosis, apocytosis and their role in the immune response (analytical review). Lab diahnostyka. 2002;3:66-72. [In Russian].

14. McIlwain DR, Berger T, Mak TW. Caspase functions in cell death and disease. Cold Spring Harb Perspect Biol. 2013;5:a008656.

15. Hridneva SV. The role of nitric oxide and lipoperoxidation processes in the development of chronic non-ulcerative colitis. Modern Gastroenterology. 2003;2:43-6. [In Russian].

16. Gubina-Vakyulyk GI, Gorbach TV, Tkachenko AS. Damage and regeneration of small intestinal enterocytes under the influence of carrageenan induces chronic enteritis. Comp Clin Pathol. 2015; 24:1473. https://doi.org/10.1007/s00580-015-2102-3

17. Tkachenko AS, Nakonechna OA, Zhukov VI, Gorbach TV, Tkachenko MO. Proteolytic degradation of poly (adp-ribose) polymerase in rats with carrageenan-induced gastroenterocolitis. Journal of V. N. Karazin' KhNU. Series 'Medicine'. 2017;34:41-46. [In Ukrainian]. 